\title{
GAMBARAN KOMPETENSI PENGAJAR DI YAYASAN WAHANA INKLUSIF INDONESIA
}

\author{
Agustin Angelia Putri \\ Fakultas Psikologi Universitas Katolik Indonesia Atma Jaya Jakarta \\ Email: angelz_putri@yahoo.co.id \\ Clara R.P. Ajisuksmo \\ Fakultas Psikologi Universitas Katolik Indonesia Atma Jaya Jakarta \\ Email: clara.as@atmajaya.ac.id
}

\begin{abstract}
Abstrak
Penelitian ini bertujuan untuk menggali gambaran kompetensi pedagogik, kompetensi kepribadian, kompetensi sosial, dan kompetensi profesional staf pengajar di Yayasan Wahana Inklusif Indonesia (YWII). YWII adalah lembaga pendidikan nonformal-inklusi yang memberikan jasa bimbingan belajar. Bimbingan belajar di YWII unik karena menggabungkan sesi belajar bagi anak berkebutuhan khusus dan non berkebutuhan khusus. Penelitian menggunakan metode kualitatif yang bertujuan untuk memperoleh gambaran secara menyeluruh dan mendalam mengenai isu atau fenomena di lingkungan sosial. Pengumpulan data dengan menggunakan wawancara dan observasi dilakukan kepada seluruh staf pengajar YWII. Kemudian, data dianalisis dengan menggunakan teknik analisis isi. Hasil penelitian menunjukkan gambaran kompetensi pengajar yang bervariasi. Pada kompetensi pedagogik, pengajar kesulitan mengenal karakteristik siswa berkebutuhan khusus dan merancang Program Pembelajaran Individual (PPI). Kompetensi kepribadian pengajar ada yang merasa bahwa pengembangan pengajar bukan tanggung jawabnya. Kompetensi sosial pengajar masih kesulitan untuk berkomunikasi dengan siswa dengan hambatan komunikasi. Kompetensi profesional pengajar bergantung pada latar belakang pendidikan dan kemampuan belajar individu.
\end{abstract}

Kata Kunci: kompetensi pengajar, pendidikan inklusi, bimbingan belajar

\begin{abstract}
This study was aimed at obtaining overview of pedagogical competencies, personality competencies, social competencies, and professional competencies of teaching staff at Yayasan Wahana Inklusif Indonesia (YWII). YWII is a non-formal-inclusive education foundation that provides tutoring services. Tutoring at YWII is unique because it combines study sessions for children with special needs and non-special needs. The study was conducted using qualitative methods that aim to obtain a comprehensive and in-depth description of social issues or phenomena. Data collection using interviews and observations made to all YWII teaching staff. Then, the data is analyzed using content analysis techniques. The results of the study show an overview of teacher competencies that vary. In pedagogic competencies, teachers have difficulty recognizing the characteristics of students with special needs and designing Individualized Education Program (IEP). Teachers' personality competencies feel that teacher development is not their responsibility. Teacher social competence is still difficult to communicate with students with communication barriers. Teacher professional competence depends on educational background and individual learning abilities.
\end{abstract}

Keywords: teacher competence, inclusive education, tutoring 


\section{PENDAHULUAN}

Yayasan Wahana Inklusif Indonesia (YWII) adalah lembaga yang bergerak di bidang Pendidikan Inklusi, khususnya bimbingan belajar dan konseling. YWII didirikan pada 19 September 2013, dan masih terus berkembang sampai sekarang. Visi YWII adalah mewujudkan masyarakat inklusif yang didalamnya tercapai penghargaan terhadap martabat penyandang disabilitas;pemenuhan dan perlindungan hak-hak serta partisipasi penuh mereka dalam kegiatan masyarakat. Bimbingan belajar adalah salah satu bentuk layanan dari YWII yang beroperasi secara aktif. Dari total tujuh staf, lima diantaranya adalah staf pengajar. Hingga penelitian dilaksanakan, sudah ada empat puluh orang siswa yang belajar di YWII. Empat orang di antaranya adalah siswa non-disabilitas, dan yang lainnya adalah siswa disabilitas dari jenjang usia dini (2,5 tahun) hingga remaja akhir (18 tahun). Sistem pembelajaran dilakukan secara klasikal maupun individual tergantung pada kebutuhan dan waktu sesi siswa. Bimbingan belajar di YWII unik karena menggabungkan sesi belajar anak berkebutuhan khusus dan non berkebutuhan khusus. Proses pembelajaran mengacu pada kurikulum pemerintah dan prinsip pendidikan inklusi.

Arikunto (1993) mengemukakan bahwa pengajar merupakan unsur yang mempunyai peran penting bagi terwujudnya pembelajaran, menurut kualitas yang dikendaki. Staf pengajar adalah pihak yang perlu mengenal siswanya karena nantinya akan terlibat dalam proses pembelajaran bersama siswa. Staf pengajar berinteraksi dengan siswa dan memberi teladan pada siswanya. Hubungan antara siswa dan staf pengajar berperan penting dalam pembelajaran di kelas. Prestasi belajar siswa tergantung pada kesiapan staf pengajar untuk melakukan kegiatan belajar yang didukung oleh pengetahuan dan keterampilan staf pengajar, sikap dan praktik (Tanang, H. \& Abu, $B$, 2014). Staf pengajar diharapkan memiliki keterampilan dan pengetahuan yang mumpuni dalam menghadapi siswa. Oleh sebab itu, sangat penting bagi seorang staf pengajar sudah memiliki pengetahuan dan kemampuan dasar sebelum mampu menghadapi siswanya.

Barghava \& Pathy (2011) menyatakan bahwa faktor terpenting dalam pembelajaran adalah pengajar. Kompetensi pengajar yang optimal akan berpengaruh secara positif terhadap proses belajar mengajar di kelas (Werdayanti, 2008), yang kemudian mempengaruhi prestasi siswa. Kompetensi pengajar berpengaruh positif dan signifikan terhadap hasil belajar siswa (Sutardi \& Sugiharsono, 2016). Pembelajaran yang optimal memerlukan pengajar yang kompeten.

Peraturan Pemerintah Nomor 19 Tahun 2005 tentang Standar Nasional Pendidikan menyatakan bahwa baik lembaga pendidikan formal maupun nonformal, harus memiliki staf pengajar yang memenuhi kompetensi dasar pengajar. Kompetensi pengajar terbagi menjadi kompetensi pedagogik, kompetensi kepribadian, kompetensi sosial, dan kompetensi profesional. Pada praktik di YWII, staf pengajar menunjukkan kompetensi yang kurang memadai sehingga hasil 
pembelajaran kurang optimal. Kompetensi pedagogik adalah kemampuan pengajar menyelenggarakan pembelajaran. Ada staf pengajar YWII yang tidak memahami PPI dan kurang mengenali siswa. Kompetensi sosial dilihat dari kemampuan berkomunikasi pengajar. Staf pengajar masih ada yang kesulitan berkomunikasi dengan siswa berkebutuhan khusus. Kompetensi kepribadian merupakan kepribadian pengajar yang dewasa dan jadi teladan bagi siswa. Staf pengajar merasa cemas memberikan contoh yang buruk bagi siswa. Kompetensi profesional dilihat dari penguasaan disiplin ilmu seorang pengajar. Staf pengajar berasal dari latar belakang pendidikan yang berbeda sehingga penguasaannya terhadap disiplin ilmu yang dibawakan dalam sesi belajar bervariasi. Perilaku-perilaku tersebut menunjukkan kesenjangan dari kompetensi yang diharapkan dimiliki seorang pengajar.

Di YWII, peran guru dijalankan oleh staf pengajar, sehingga staf pengajar dituntut untuk memiliki empat kompetensi dasar tersebut. Pada observasi dan wawancara awal ditemukan adanya kesenjangan antara kompetensi yang seharusnya dimiliki pengajar dan kenyataan di YWII. YWII tidak memiliki panduan standar kompetensi pengajar, namun dalam pelaksanaannya staf pengajar mengikuti kurikulum sekolah yang diterapkan pemerintah. Penelitian ini berusaha menggali gambaran empat kompetensi pengajar yang ada di YWII sesuai indikator yang ditetapkan pemerintah. Adanya kesenjangan antara empat kompetensi pengajar dengan gambaran empat kompetensi pengajar di YWII tersebut kemudian bisa menjadi bahan masukan untuk pengembangan YWII dalam sektor Bimbingan Belajar.

\section{METODE}

Penelitian ini menggunakan metode penelitian kualitatif. Creswell (2012) menjelaskan bahwa metode kualitatif bertujuan untuk memperoleh gambaran secara menyeluruh dan mendalam mengenai isu atau fenomena di lingkungan sosial. Penelitian ini berupaya mengangkat dan menganalisis fenomena yang terjadi pada staf pengajar di YWII secara mendalam. Penelitian ini dilakukan dengan melakukan wawancara individu kepada seluruh staf pengajar berjumlah lima orang, satu orangtua siswa, dan dua siswa. Selain itu, juga dilakukan observasi di kelas dan di luar kelas. Wawancara dan observasi dimaksudkan untuk memperoleh informasi mengenai gambaran keempat kompetensi pengajar di YWII. Pengambilan data penelitian dilakukan di YWII, Depok, antara Juni 2018 hingga Agustus 2018.

Variabel penelitian ini adalah empat kompetensi pengajar, yaitu kompetensi pedagogik, kompetensi kepribadian, kompetensi sosial, dan kompetensi profesional. Instrumen penelitiannya menggunakan wawancara semi terbuka dan observasi secara naratif. Panduan observasi dan wawancara menggunakan indikator yang diturunkan dari empat kompetensi pengajar tersebut. Hasil 
data dari wawancara dan observasi kemudian diolah menggunakan teknik analisis isi. Pertama, data dituliskan kemudian dilakukan koding berdasarkan variabel penelitian. Hasil koding data tersebut diinterpretasi untuk menjadi hasil penelitian.

\section{HASIL DAN PEMBAHASAN}

Hasil penelitian berupa gambaran kompetensi pengajar dilihat berdasarkan keempat kompetensi pengajar yang menjadi indikator variabel penelitian.

\section{Kompetensi Pedagogik}

Kompetensi pedagogik yang dimiliki staf pengajar bervariasi setiap individunya, namun secara umum staf pengajar mengetahui karakteristik siswa, mengacu pada kurikulum saat persiapan materi belajar, berusaha menjalankan proses belajar mengajar yang terdidik, mengevaluasi proses belajar dan memberikannya pada orangtua siswa demi perkembangan siswa lebih lanjut. Pada indikator teori belajar, staf pengajar tidak mengetahui dan bahkan ada yang menganggap bahwa teori belajar tidak penting dibandingkan kenyataan di lapangan. Latar belakang pendidikan dan pengalamanan sebelumnya adalah faktor yang bisa menyebabkan kompetensi pedagogik staf pengajar bervariasi. Staf pengajar belajar secara otodidak dan mengacu pada pemahamannya sendiri saat menyelenggarakan pembelajaran.

\section{Kompetensi Kepribadian}

Kompetensi kepribadian ditunjukkan oleh staf pengajar melalui sikap dan perilaku dalam kegiatan di YWII. Staf pengajar secara umum mengetahui bahwa kunci utama menghadapi siswa berkebutuhan khusus adalah sabar dan tegas. Setiap staf pengajar mempelajari hal tersebut dari pengalaman sebelumnya, dan ada juga yang otodidak. Setiap staf saling berkomunikasi saat mengalami masalah dalam menghadapi siswa. Ada satu staf pengajar yang dianggap handal dalam menghadapi siswa yang punya masalah sikap karena ketegasannya, sehingga sering diminta untuk menjadi pengajar siswa tersebut. Kompetensi kepribadian di YWII sangat tergantung pada persepsi pengajar mengenai pengajar yang ideal, sehingga tidak seragam antar staf pengajar.

\section{Kompetensi Sosial}

Kompetensi sosial yang dimiliki staf pengajar secara umum menunjukkan hasil yang cukup. Staf pengajar mampu berkomunikasi dengan rekan kerja, orangtua siswa, dan siswa secara santun dan efektif. Siswa merasa nyaman untuk berkomunikasi dengan staf pengajar di dalam dan luar kelas. Orangtua siswa juga merasa bahwa staf pengajar sangat memperhatikan perkembangan anaknya dan mau diajak berkomunikasi kapan saja. Staf pengajar masih sulit berkomunikasi dengan siswa yang memiliki hambatan sosial, sehingga komunikasi dilakukan satu arah dan berulang. Hambatan komunikasi dengan rekan kerja muncul dalam komunikasi di YWII karena kurangnya 
waktu untuk berkomunikasi langsung. Hal ini bisa menyebabkan masalah antar rekan kerja dan membuat iklim kerja menjadi kurang nyaman. Pendidikan berisi suatu interaksi antara pendidik dan peserta didik sebagai usaha untuk membantu peserta didik dalam mewujudkan tujuan-tujuan pendidikan (Sukmadinata, 1998). Komunikasi antar pengajar dan siswanya sangat penting untuk mencapai tujuan pendidikan.

\section{Kompetensi Profesional}

Kompetensi profesional staf pengajar bergantung pada penguasaan disiplin ilmu individu. Secara umum, staf pengajar tidak memiliki banyak waktu untuk mempersiapkan materi sehingga sangat bergantung dari sejauh mana materi siswa di sekolah. Staf pengajar akan mempersiapkan materi jika sudah dekat waktunya, seperti H-1 atau hari H. Materi yang diajarkan staf pengajar disesuaikan dengan pelajaran di sekolah dan mengacu pada standar kompetensi per materi sehingga pelajaran di sekolah dan YWII selalu sejalan. Staf pengajar melakukan tindakan reflektif dengan menulis catatan kegiatan dan catatan perkembangan siswa. Staf pengajar yang tidak merasa memiliki masalah dalam sesi belajar akan terus menggunakan metode belajarnya, dan staf pengajar umumnya hanya menggunakan satu metode saat mengajar seperti metode ceramah.

\section{PENUTUP}

\section{Simpulan}

Berdasarkan hasil data yang sudah dianalisis, maka dapat disimpulkan beberapa hal. Pertama, gambaran kompetensi pengajar di YWII sangat bervariasi. Kedua, terkait kompetensi pedagogik, staf pengajar masih belum memahami karakteristik anak berkebutuhan khusus, kurang memahami perancangan Program Pembelajaran Individu (PPI), dan persiapan mengajar yang tidak keluar dari rutinitas. Ketiga, gambaran kompetensi kepribadian staf pengajar YWII kesulitan untuk menjadi pribadi yang sabar sekaligus tegas pada siswa. Keempat, kompetensi sosial staf pengajar YWII secara umum mengalami hambatan pada komunikasi dengan siswa yang punya hambatan komunikasi. Kelima, gambaran kompetensi profesional staf pengajar YWII bervariasi tergantung pada latar belakang pendidikan dan pengalaman mengajar sebelumnya.

\section{Saran}

Pengembangan kompetensi staf pengajar penting dilakukan untuk mengembangkan pembelajaran siswa. YWII dapat mengikutsertakan staf pengajar dalam pelatihan atau seminar mengenai pengembangan kompetensi pengajar. Usaha pribadi dan berkelanjutan diharapkan dapat dilakukan oleh seluruh staf pengajar dalam mengembangkan kompetensinya sebagai pengajar. Penyusunan standar kompetensi pengajar yang disesuaikan dengan tujuan YWII dapat dilakukan dalam bentuk penelitian lanjutan. 


\section{DAFTAR PUSTAKA}

Arikunto, S. (1993). Manajemen Pengajaran Secara Manusiawi. Jakarta: Rineka Cipta.

Bhargava, A. \& Pathy, M. (2011). Perception of student teachers about teaching competencies. Journal of Contemporary Research 1 (1), 77.

Creswell, J. W. (2012). Educational research (Ed. Ke-4). Boston: Pearson Education, Inc.

Departemen Pendidikan Nasional Republik Indonesia. (2005). Undang-Undang Republik Indonesia Nomor 20 Tahun 2005 tentang Sistem Pendidikan Nasional. Jakarta: Biro Hukum dan Organisasi Sekretariat Jendral Departemen Pendidikan Nasional.

Sukmadinata, N.S. (2006). Metode Penelitian Kualitatif. Bandung: Graha Aksara.

Sutardi dan Sugiharsono. (2016). Pengaruh Kompetensi Guru, Motivasi Belajar, dan Lingkungan Keluarga Terhadap Hasil Belajar Mata Pelajaran Ekonomi. Harmoni Sosial: Jurnal Pendidikan IPS, Vol.3 No.2.

Tanang, H. dan Abu, B. (2014). Teacher Professionalism and Professional Development Practices in South Sulawesi, Indonesia. Journal of Curriculum and Teaching, 3(2),25-42. doi:10.5430/jct.v3n2p25

Werdayanti, A. (2008). Pengaruh Kompetensi Guru Dalam Proses Belajar Mengajar Di Kelas dan Fasilitas Guru Terhadap Motivasi Belajar Siswa. Jurnal Dinamika Pendidikan: Departemen Pendidikan Ekonomi UNNES. Vol.3, No.1. 